\title{
A HARZBURGITE TO GARNET LHERZOLITE TRANSFORMATION: THE POSSIBLE ROLES OF STRAIN AND METASOMATISM
}

\author{
J B Dawson \\ University of Edinburgh, Scotland, U.K.
}

It is generally accepted that garnet lherzolite is a major rock-type in the Earth's upper mantle and the parent of a variety of basic/ultrabasic magmas and their complementary refractory residues. Despite its pivotal role in upper mantle processes, the term "garnet lherzolite" had been applied loosely to what is, in fact, a heterogeneous group of rocks containing varying modal contents of the four major phases (forsterite, enstatite, Cr-diopside and pyrope garnet), and the chemistry of the pyroxenes and garnets is variable. (Dawson et al. 1980). These variations suggest that variants of garnet peridotite may have different origins.

One postulated origin, based on high-PT experimentation, is that a high- $\mathrm{T}$ harzburgite precursor was converted to garnet lherzolite when garnet and clinopyroxene were generated by exsolution from orthopyroxene on cooling (O'Hara et al., 1975; Canil, 1992). This suggested origin has been confirmed by direct observation on lherzolite nodules from South African kimberlites in which porphyroclasts of enstatite contain exsolved garnet, diopside and spinel (Dawson et al 1980); further, integrated analyses of the enstatites plus exsolved garnet and diopside match the compositions of high-Ca-Al enstatites in so-called "fertile" harzburgites which can hold 16-18wt\% garnet and 5-6wt\% diopside in solid solution (Hervig et al. 1980). (This would translate as 5-6 wt.\% garnet and 1$2 \mathrm{wt} . \%$ diopside in a rock consisting originally of $65 \%$ olivine, $35 \%$ enstatite). Additional indirect support comes from textural studies on garnet lherzolites in which an exsolution origin can be inferred for the garnet and clinopyroxene by their consistent, close spatial association with enstatite (Cox et al 1987; Saltzer et al., 2001).

Thus, based on experimental, textural and major element data, a convincing case can be made for an exsolution origin of some lherzolites containing small amounts of garnet and diopside. However, trace element data relating to the exsolution process are still lacking. Theoretically, in the absence of other complicating factors, the types and contents of the trace elements in the phases that have exsolved from enstatite should reflect those of the parent orthopyroxene..

This aspect has been addressed by (i) by making major and trace element analyses of enstatite, garnet and diopside formed when the garnet and diopside exsolved from orthopyroxene in a lherzolite from the kimberlite of the Monastery Mine, South Africa; and (ii) by comparing these data with new trace element data for enstatites from two fertile harzburgites (potential parental rocks in the exsolution hypothesis).

\section{Exsolved Iherzolite.}

Sample BD1366 is an inequigranular peridotite containing orthopyroxene porphyroclasts (up to $15 \mathrm{~mm}$ ) set in a finer matrix mainly of polygonal olivine with rarer grains of red garnet and green diopside. The enstatite porphyroclasts are cut by numerous brittle micro-fractures (kink bands); some are normal to the cleavage whereas others are at a high angle and, between the high-angle fractures, the enstatite subgrains are rotated. Within the enstatite crystals, abundant garnet, and rarer diopside and chromite, grains of differing morphology have exsolved as equant grains in the kink-bands and as lamellae or elongate pods parallelling or cutting across the cleavage. Equant grains of garnet and diopside also form "necklaces" around the edge of enstatite porphyroclasts, though some equant garnet is embedded in the lamellae-free margins of the enstatite grains. The garnet and diopside necklace grains, together with enstatite neoblasts are occasionally surrounded by intergranular chromite.

Mineral analyses were made by W.D.S on a Camebax Microbeam electron microprobe and by SIMS spectrometry using a Cameca imf-4f ion microprobe. The individual phases are chemically uniform, regardless of morphology or proximity to other phases. Major and minor oxide analyses are given in Table 1.

Table 1: Phases in 1366 Olivine Enstatite Diopside Garnet Spinel

\begin{tabular}{lccccc}
\hline$n$ & 7 & 39 & 37 & 50 & 12 \\
\hline $\mathrm{SiO}_{2}$ & 40.44 & 57.02 & 53.95 & 41.72 & 0.05 \\
$\mathrm{TiO}_{2}$ & 0.00 & 0.00 & 0.00 & 0.00 & 0.00 \\
$\mathrm{Al}_{2} \mathrm{O}_{3}$ & 0.02 & 0.87 & 1.98 & 22.00 & 16.15 \\
$\mathrm{Cr}_{2} \mathrm{O}_{3}$ & 0.02 & 0.27 & 1.50 & 2.55 & 53.28 \\
$\mathrm{Fe} 2 \mathrm{O} 3$ & & 3.16 & 1.45 & 1.75 & 3.64 \\
$\mathrm{FeO}$ & $6.71^{*}$ & 1.38 & 0.12 & 5.64 & 13.76 \\
$\mathrm{MnO}$ & 0.09 & 0.09 & 0.05 & 0.41 & 0.26 \\
$\mathrm{NiO}$ & 0.43 & 0.1 & 0.06 & 0.02 & 0.10 \\
$\mathrm{MgO}$ & 52.2 & 37.07 & 17.01 & 20.96 & 13.52 \\
$\mathrm{CaO}$ & 0.01 & 0.23 & 21.86 & 4.98 & 0.00 \\
$\mathrm{Na} 2 \mathrm{O}$ & na & 0.04 & 1.46 & 0.01 & 0.00 \\
Total & 99.91 & 100.22 & 99.43 & 100.05 & 100.77
\end{tabular}

*All iron as $\mathrm{Fe} 2$

The olivine, with a high $\mathrm{Mg} /(\mathrm{Mg}+\mathrm{Fe})$ ratio of 0.932 , is more similar to olivines in harzburgites than to those in garnet lherzolites. The enstatite $\left(\mathrm{Mg} /\left[\mathrm{Mg}+\mathrm{Fe}^{2+}\right]\right.$ 0.94) is more magnesian than other mantle enstatites with the exception of those in barren harzburgites,. The garnet chemistry chemistry lies within the range for chrome 
pyrope (group 9 of Dawson and Stephens, 1975), the commonest type of garnet in garnet lherzolites. The clinopyroxene composition lies within the $\mathrm{Cr}, \mathrm{Fe}, \mathrm{Mg}$ and $\mathrm{Ca}$ and $\mathrm{Na}$ ranges for chrome-diopside (Stephens and Dawson, 1977) - the commonest type of garnet in garnet lherzolites. The spinel is an aluminous chromitewhose $\mathrm{Cr} /(\mathrm{Cr}+\mathrm{Al})$ value of 0.69 and $\mathrm{Mg} /(\mathrm{Mg}+\mathrm{Fe})$ ratio of 0.64 is bets matched by spinels in garnet-chromite lherzolites rather than those in refractory chromite harzburgites (Smith and Dawson, 19 1975). In all the phases, $\mathrm{TiO} 2$ was not detectable with the electron microprobe.

Trace element concentrations are shown graphically in Figs 1 and 2. $\mathrm{V}, \mathrm{Sr}, \mathrm{Zr}$ and the LRREE and MREE partition preferentially into clinopyroxene, whilst contains the lowest amounts of most elements; Sc is highest in garnet. A particular feature of all phases is the low amounts of $\mathrm{TiO}_{2} \quad(<30 \mathrm{ppm})$, contrasting particularly with garnet and diopside in most mantle peridotites. Because the major-element chemistry of BD1366 exsolved garnet and diopside most closely matches analogous phases in cold granular garnet lherzolites (GGL), their trace element concentrations are compared with similar phases (Shimizu, 1975; Shimizu and Allègre, 1978) on Figs 3 and 4. Sc, V, Cr, $\mathrm{Mn}$ and $\mathrm{Sr}$ amounts in garnet and diopside in both groups are similar, but 1366 garnet and diopside contain lower $\mathrm{Ti} \mathrm{Co}$ and $\mathrm{Zr}$ than their counterparts in GGL (Fig.3). Compared with the sinusoidal chondrite normalised REE pattern for GGL garnet, the pattern for 1366 garnet is relatively flat and, except for the HREE, concentrations are around 1-order of magnitude lower (Fig.4). The REE pattern for BD1366 clinopyroxene is similar to that for GGL clinopyroxen (high LREE, relatively low HREE), but the LREE are higher, and HREE lower, in the 1366 clinopyroxene.

\section{Comparison with harzburgite enstatites}

Trace element analyses have been made on enstatites from two fertile $(\mathrm{FH})$ and one barren harzburgite $(\mathrm{BH})$ analysed previously for major and minor elements (Hervig et al 1980). Major element concentrations in the enstatites in FH BD1781, FH BD2004, and $\mathrm{BH}$ BD1919 are respectively $\mathrm{Al}_{2} \mathrm{O}_{3} 3.56 \mathrm{wt} \%, 3.60$ and 1.81; $\mathrm{Cr}_{2} \mathrm{O}_{3}$ 0.96, 0.92 and 0.46; $\mathrm{CaO} 1.17,0.95$ and 0.34 . The trace element data, shown graphically in Fig 5 , show the extremely low trace-element concentrations in these enstatites; for some elements the amounts are below detection. This is despite the high amounts of $\mathrm{Al}$, $\mathrm{Cr}$ and $\mathrm{Ca}$ in the $\mathrm{FH}$ enstatites. The most complete REE pattern (for FH 2004) is almost flat at around 0.01 to 1 $\mathrm{CN}$. More important, any phases exsolving from the $\mathrm{FH}$ enstatites would clearly have been able to inherit only very low amounts of trace elements from this parental enstatite. Comparative data for peridotite orthopyroxenes are scarce, but REE patterns in enstatites in anhydrous spinel peridotites from Germany, Mongolia and San Carlos (Stosch, 1982) have a shallow, positive slope (LREE<HREE) ; concentrations are slightly higher than in FH2004.

Compared with FH2004 enstatite trace elements, the enstatite in 1366 contains lower amounts of all elements shown in Fig.5, with the exception of $\mathrm{Nb}$, whereas garnet and clinopyroxene contain higher or similar amounts. Hence, depending upon a relatively low volume of exsolved garnet+clinpyroxene to "residual" orthopyroxene, and excepting the data for $\mathrm{Nb}$, the trace element data can support the evolution of the phases in 1366 from enstatite of the chemistry similar to that in fertile harzburgite 2004. The relatively high amounts of $\mathrm{Nb}$ in all 1366 phases, cannot derive from a FH2004-type enstatite; some additional source is required.

\section{Discussion}

1. The major and minor element chemistry of the phases in BD1366 shows that the olivine most closely matches harzburgite olivines and, prior to expulsion of $\mathrm{Ca}, \mathrm{Al}$ and $\mathrm{Cr}$ from its lattice in the form of the exsolved garnet, diopside and chromite, the enstatite would have been most similar to the high-Ca-Al enstatites found in fertile harzburgites. Thus, on textural grounds, and on the major and minor element chemistry of the phases, there are reasonable grounds for interpreting BD1366 as representing a transition from fertile harzburgite to garnet lherzolite.

2. Assuming that the initial trace element concentrations in the enstatite in BD1366 are similar to that in the FH2004 enstatite, with the sole exception of $\mathrm{Nb}$, the trace element contents of the residual host enstatite and the exsolved garnet and diopside are compatible with an iso-chemical exsolution origin .

3. Compared with data for transition elements and REE in granular garnet lherzolites, the garnets and clinopyroxenes in 1366 contain lower $\mathrm{Ti}, \mathrm{Co}, \mathrm{Zr}$ and, for garnet, most of the REE., Compared with phases in sheared garnet lherzolites (Shimizu and Allègre, 1978), the amounts of $\mathrm{Ti}$ and $\mathrm{Zr}$ are even lower.

4. The modal compositions (5-10\% garnet, $2-5 \%$ clinopyroxene) of many garnet lherzolites suggests that they may be of exsolution origin (Dawson et al., 1980; Saltzer et al ., 2001). Assuming this to be the case, and also assuming their parental harzburgite orthopyroxenes to have a trace element budget similar to that in FH2004, the trace element contents of GGL (and even more so in sheared garnet lherzolites) cannot result from isochemical exsolution. Metasomatic addition of $\mathrm{Ti}, \mathrm{Zr}$, the LREE and, in the case of clinopyroxenes, Sr must have taken place during their formation.

5. Garnet lherzolites with large orthopyroxene porphyroclasts are envisaged as being texturally intermediate between a coarse-grained harzburgite precursor and granular garnet lherzolite of 
"normal" grain size (Dawson et al., 1980). The continued strain necessary complete the harzburgite-GGL transformation, resulting in the more complete recrystallisation typical of the GGL, appears to coincide with the inferred metasomatism

6. Ideally, after their formation, fertile harzburgite enstatites should exsolve garnet and diopside when the temperature falls to that of the ambient upper mantle (Canil, 1991). The failure of some fertile harzburgites to invert to garnet lherzolite suggests that there must be some reason(s) additional to temperature drop to assist their inversion to garnet lherzolite. The link between exsolution and deformation in BD1366 may indicate that the initial exsolution also depends upon strain, the presence of which is obscured by the more complete recrystallisation typical of GGL. Conversely, the survival of fertile harzburgites might depend upon siting in strain-free areas of the upper mantle.

\section{References}

Canil, D. 1991. Experimental evidence for the exsolution of cratonic peridotite from high-temperature harzburgite, Earth Planet. Sci.Letts106, 64-72.

Canil, D. 1992. Orthopyroxene stability along the peridotite solidus and the origin of cratonic lithosphere beneath southern Africa. Earth Planet. Sci.Letts 111, 83-95

Cox, K.G., Smith, M.R., Beswetherick S. 1987. Textural studies of garnet lherzolites: evidence of exsolution from high-temperature harzburgites. In: Nixon, P.H. (Ed.), Mantle xenoliths Wiley, Chichester, pp.537550

Dawson, J.B. , Stephens, W.E. 1975. Statistical classification of garnets from kimberlite and associated xenoliths. Jl Geol. 83, 589-607.

Dawson, J. B., Smith, J.V., Hervig, R.L. 1980. Heterogeneity in upper-mantle lherzolites and harzburgites. Phil. Trans. R. Soc. Lond. A297, 323331.

Gurney, J.J., Harte, B., Cox, K.G. 1975. Mantle xenoliths in the Matsoku kimberlite pipe. Phys. Chem. Earth 9, 507-523.

Harte, B., Gurney, J.J. 1975. Evolution of clinopyroxene and garnet in an eclogite nodule from the Roberts Victor kimberlite pipe, South Africa. Phys. Chem. Earth 9, 367-387.

Hervig, R.L., Smith, J.V., Steele, I .M., Dawson, J.B. 1980. Fertile and barren Al-Cr spinel harzburgites from the upper mantle: ion and electron probe analyses of trace elements in olivine and orthopyroxene: relation to lherzolites. Earth Planet. Sci.Letts 50, 41-58.

O’Hara, M.J., Saunders, M.J., Mercy, E.P.L. 1975. Garnet peridotite, primary ultrabasic magma and eclogite; interpretation of upper mantle processes in kimberlite. Phys. Chem.Earth 9, 571-604.

Saltzer, R.L., Chatterjee, N. ,Grove, T.L. 2001. The spatial relationship of garnets and pyroxenes in mantle peridotites; pressure-temperature history of peridotites from the Kaapvaal craton. J1 Petrol. 42, 2215-2229.

Sautter, V. , Harte, B. 1988. Diffusion gradients in an eclogite xenolith from the Roberts Victor kimberlite pipe; (1) mechanism and evolution of garnet exsolution in $\mathrm{Al}_{2} \mathrm{O}_{3}$-rich clinopyroxene. Jl.Petrol. $29,1325-1358$.

Shimizu, N. 1975. Rare earth elements in garnets and clinopyroxenes from garnet lherzolite nodules in kimberlites. Earth Planet. Sci. Letts 25, 26-32.

Shimizu, N. Allègre, C. 1978. Geochemistry of transition elements in garnet lherzolite nodules in kimberlites. Contrib. Mineral. Petrol. 67, 41-50

Stosch, H.-G. 1982. Rare earth element partitioning between minerals from anhydrous spinel peridotite xenoliths. Geochim. Cosmochim. Acta 46, 793-811.

Smith, J.V. , Dawson, J.B. 1975. Chemistry of Ti-poor spinels, ilmenites and rutiles from peridotite and eclogite xenoliths. Phys. Chem. Earth 9, 309-322.

Stachel, T., Viljoen, K.S., Brey, G., Harris, J.W. 1994. Metasomatic processes in lherzolitic and harzburgitic domains of diamondiferous lithospheric mantle; REE in garnets from xenoliths and inclusions in diamonds. Earth Planet. Sci. Letts 159 $1-12$.

Stephens, W.E., Dawson, J.B. 1977. Statistical comparison between pyroxenes from kimberlites and their associated xenoliths. J1. Geol. 85, 433-449.

Contact: JB Dawson, Dept of Geology and Geophysics, University of Edinburgh, EH9 3JW, U.K., Email:jbdawson@glg.ed.ac.uk 

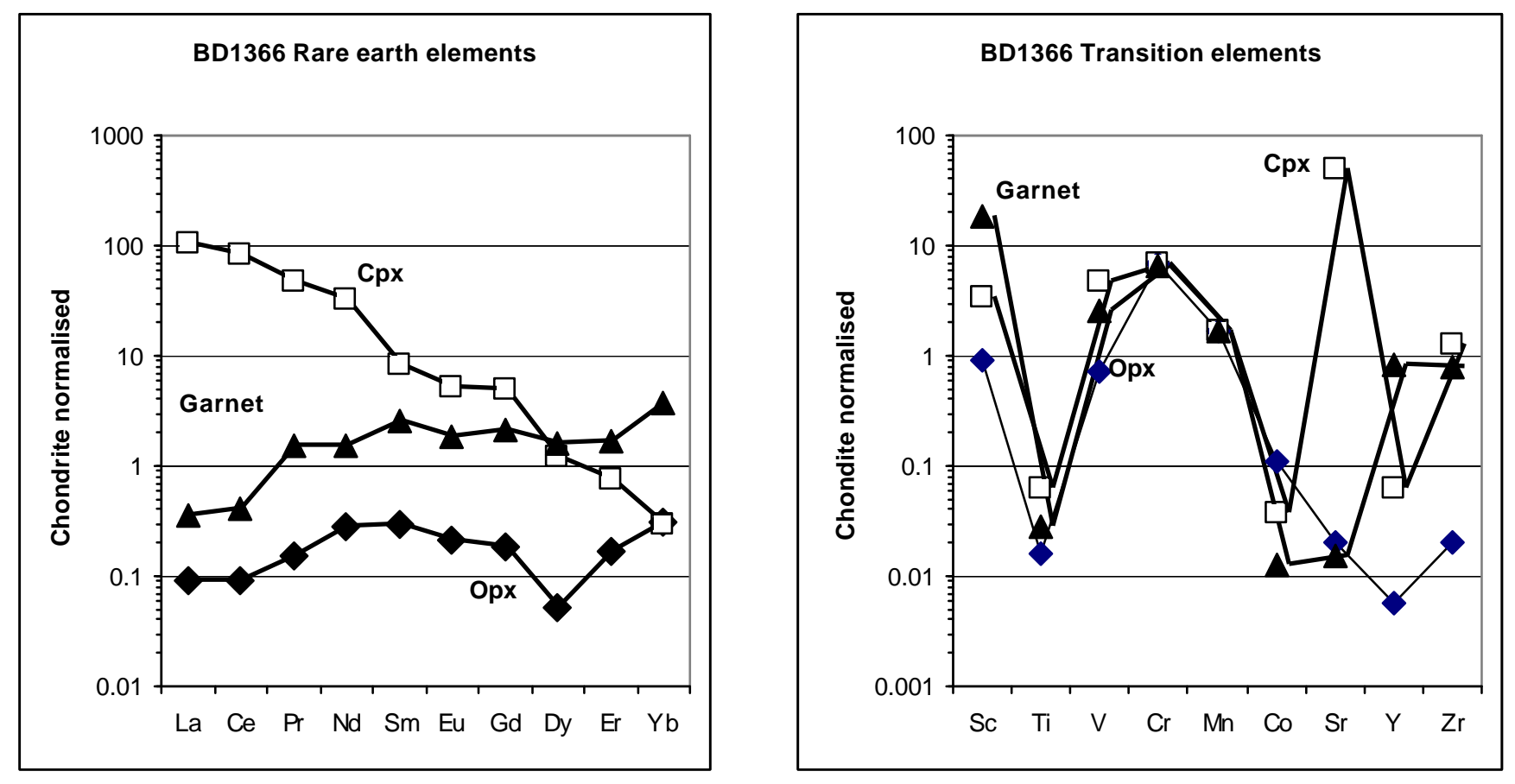

Figures 1 and 2
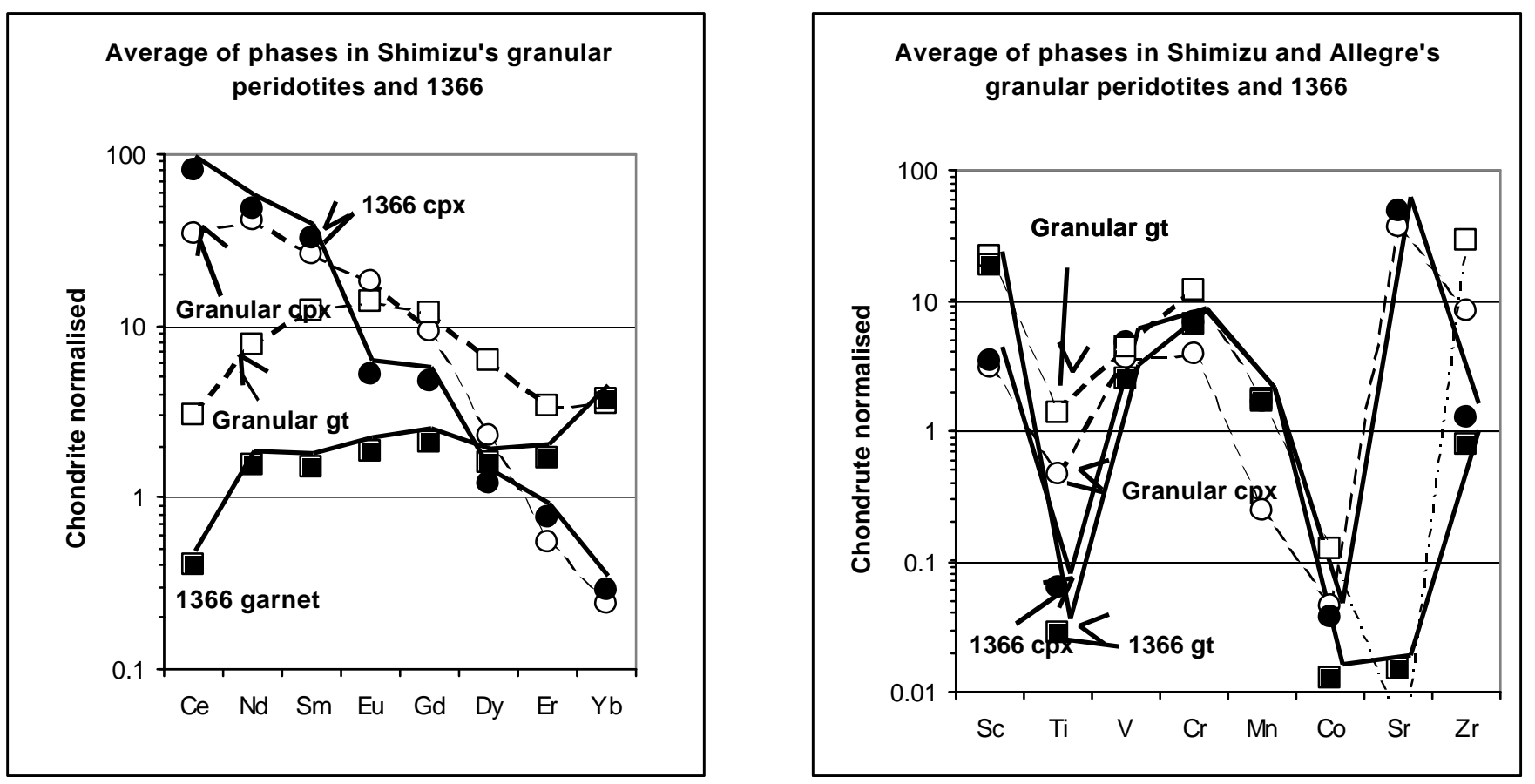

Figures 3 and 4 


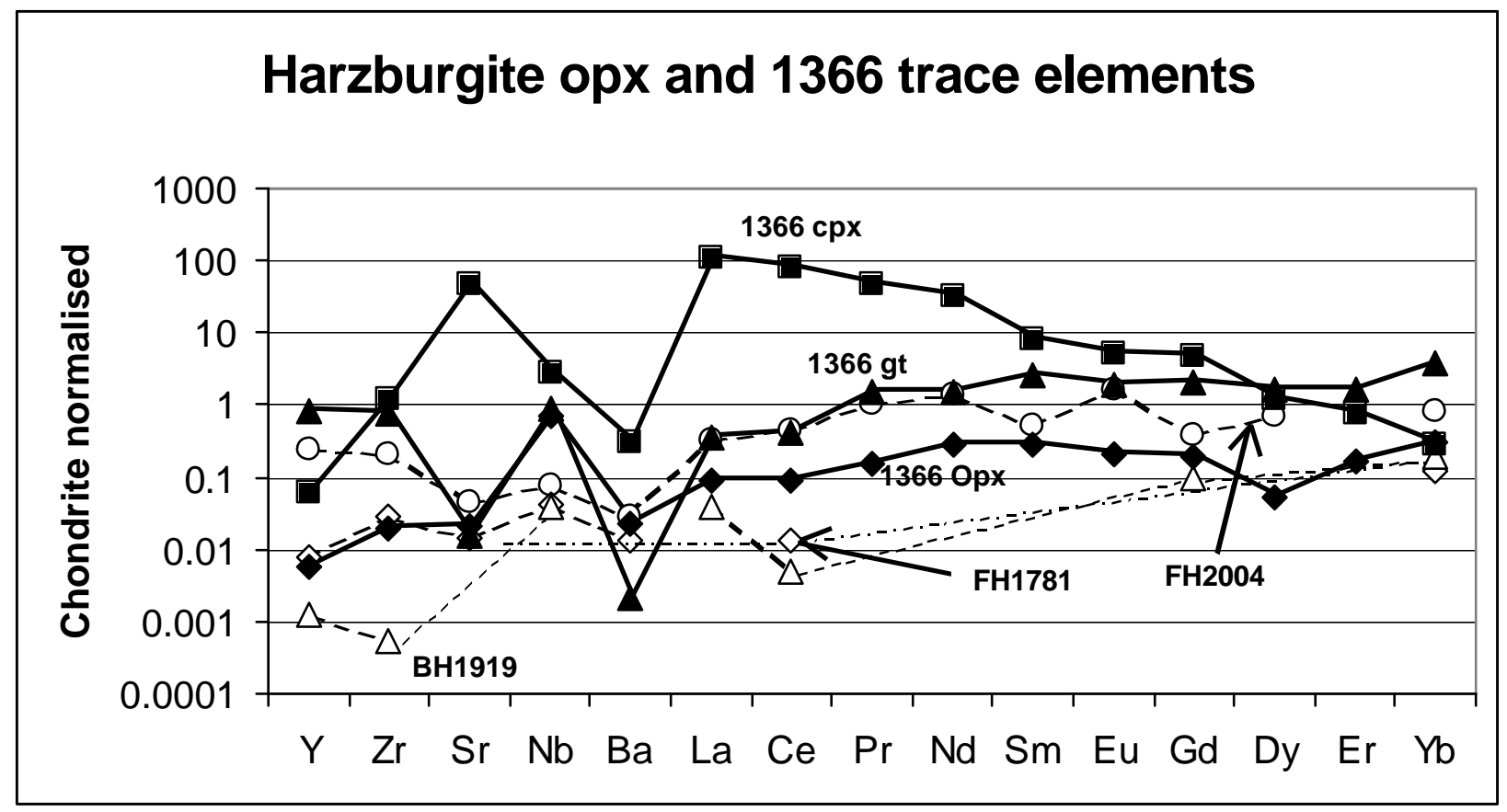

Figure 5 